\section{Particle Size of Volcanic Tuff Improves Shoot Growth and Flower Quality of Asiatic Hybrid Lily Using Soilless Culture}

\author{
Malik G. Al-Ajlouni ${ }^{1}$, Jamal Y. Ayad, and Yahia A. Othman
}

AdDitionAL INDEX WORDs. bulb, cut flower, Lilium $\times$ elegans

SUMMARY. Soilless substrates enhance growing environment, nutrient content, and water quality in the growing medium. The objective of this study was to assess the influence of substrate particle size on growth and flower quality (flower number and length per plant) of two asiatic hybrid lily (Lilium $\times$ elegans) cultivars Fangio and Ercolano. Plants were grown in 12-L pot under greenhouse conditions. Five grades of particle-size substrate, consisting of granulated volcanic material (tuff) were used as treatments. These sizes were 0 to 2,0 to 4,0 to 8,2 to 4 , and 4 to $8 \mathrm{~mm}$.

Fertigation was applied daily. Plant morphology, physiology, and flower quality were determined during flowering stage. Treatments of 2 to 4 - and 4 to 8 - $\mathrm{mm}$ tuff had lower water holding capacity (WHC), bulk density, electrical conductivity (EC), and $\mathrm{pH}$ compared with 0 to 2 - and 0 to $4-\mathrm{mm}$ tuff. In addition, plant height, leaf area, and flower quality of 'Fangio' were higher compared with 'Ercolano'. Chlorophyll content and fluorescence were similar among all treatments. Leaf fresh weight, leaf area, shoot dry weight, root dry weight, and flower quality were higher in sizes of 0 to 4-, 2 to 4-, and 4 to $8-\mathrm{mm}$ than 0 to $2-\mathrm{mm}$ tuff, especially those from 'Fangio'. The 0 to $4-\mathrm{mm}$ substrate had an optimal and consistent flower quality results in both cultivars when compared with other tuff sizes. Overall, the results presented here suggest that using 0 to $4-\mathrm{mm}$ tuff substrate holds promise for improving growth and flower quality of asiatic hybrid lily grown under soilless culture.

$\mathrm{T}$ he selection of a growing medium is a key factor in soilless systems (Samadi, 2011). For successful root penetration and shoot growth, soilless substrate should have high total porosity, low bulk density, optimal WHC, and excellent stability (Deepagoda et al., 2013; Richards et al., 1986). Water-deficit conditions can decrease nutrient uptake, reduce plant growth, and may cause plants to permanently wilt (Deepagoda et al., 2013; Hu and Schmidhalter, 2005), and excess water conditions may reduce microbial activity, nutrient uptake, and root growth (García et al., 2008). Therefore, optimal water and air space management is essential to sustain a healthy rhizosphere, specifically in restricted environments, such

\footnotetext{
Department of Horticulture and Crop Science, University of Jordan, Amman, Jordan 11942

This study is based on work that was funded by the Deanship of Academic Research at the University of Jordan.

We thank our staff Hassan Munir, Tala Assaf, and Mahmoud Abadi for their assistance in the greenhouse measurements. We also thank Susan Cooper, Texas A\&M University, and Joshua Sherman, University of Arizona, for their critical review of this manuscript.

${ }^{1}$ Corresponding author. E-mail: m.ajlouni@ju.edu.jo.
} doi: 10.21273/HORTTECH03585-16 as greenhouse containers (Deepagoda et al., 2013).

Physical properties of substrate, such as particle size, are a key factor of growing medium selection (Bohne and Wrede, 2005). Growing bolboschoenus (Bolboschoenus planiculmis) seedlings in homogeneoussized quartz particles greater than $3 \mathrm{~mm}$ resulted in lower biomass, rhizome length, and spacer length (i.e., interramet distance), compared with medium $(1.5 \mathrm{~mm})$ and small $(0.75 \mathrm{~mm})$ particle substrates (Huang et al., 2013). Samadi (2011) grew cucumber (Cucumis sativus) using soilless system and diverse particle sizes of perlite and organic substrates. The substrate particle sizes were very coarse ( 2 to $3 \mathrm{~mm}$ ), coarse (1 to $2 \mathrm{~mm}$ ), medium ( $1 \mathrm{~mm}$ ), fine $(0.5$ to 1 $\mathrm{mm})$, and very fine $(<0.5 \mathrm{~mm})$. Samadi indicated that fine-grade perlite had higher fruit weight $(50 \%)$, plant height $(25 \%)$, and leaf area (70\%) compared with very-coarsegrade perlite. Richards et al. (1986) found that sieving-off coarse pine bark particles (diameter $>2 \mathrm{~mm}$ ) improved WHC and did not significantly reduce aeration levels in the growing mixture. However, changing particle-size ratio of small ( 1 to $3 \mathrm{~mm}$ ) to large ( 3 to $6 \mathrm{~mm}$ ) diameter did not affect growth of hybrid bermudagrass [Cynodon dactylon $\times$ Cynodon transvaalensis (Sloan et al., 2008)].

Proper physical properties of soilless substrate enhance plant growth and productivity (Cannavo and Michel, 2013; Deepagoda et al., 2013). A substrate with very fine particle size normally has higher WHC and less aeration compared with coarse (well-aerated) substrate (Ingram et al., 1993). Poorly aerated media may concentrate roots in the top portion of the container and increase the susceptibility to root rot pathogens and micronutrient deficiencies (Ingram et al., 1993). Although air-filled porosity was found to be the highest in coarser particles, pore effectiveness coefficient (the degree of linkage between pores) was found to decrease with the increasing coarseness of the substrate (Caron et al., 2005). Murphy et al. (2013) found that coarse substrate (particles $>4 \mathrm{~mm}$ ) inhibited growth possibly by creating excessively large pores. In fine particle substrate (relatively low air-filled porosity), oxygen deficiency in root rhizosphere might occur when plants exhibit high growth rates and intensive root respiration (Allaire et al., 1996). Overall, particle size influences the substrate porosity, WHC, and plant growth parameters (Munoz et al., 1993).

\begin{tabular}{llll}
\hline $\begin{array}{l}\text { Units } \\
\text { To convert U.S. to SI, } \\
\text { multiply by }\end{array}$ & U.S. unit & SI unit & $\begin{array}{l}\text { To convert SI to U.S., } \\
\text { multiply by }\end{array}$ \\
\hline 3.7854 & gal & $\mathrm{L}$ & 0.2642 \\
2.54 & inch(es) & $\mathrm{cm}$ & 0.3937 \\
25.4 & inch(es) & $\mathrm{mm}$ & 0.0394 \\
6.4516 & inch & $\mathrm{cm}^{2}$ & 0.1550 \\
1 & $\mathrm{mmho} / \mathrm{cm}$ & $\mathrm{dS} \cdot \mathrm{m}^{-1}$ & 1 \\
28.3495 & $\mathrm{oz}$ & $\mathrm{g}$ & 0.0353 \\
1.7300 & $\mathrm{oz} / \mathrm{inch}^{3}$ & $\mathrm{~g} \cdot \mathrm{cm}^{-3}$ & 0.5780 \\
1 & $\mathrm{ppm}$ & $\mathrm{mg} \cdot \mathrm{L}^{-1}$ & 1 \\
$\left({ }^{\circ} \mathrm{F}-32\right) \div 1.8$ & ${ }^{\circ} \mathrm{F}$ & ${ }^{\circ} \mathrm{C}$ & $\left({ }^{\circ} \mathrm{C} \times 1.8\right)+32$
\end{tabular}


Volcanic tuff is widely used in Jordan and many other Mediterranean countries for growing cut flower plants including lily (Lilium sp.). Tuff substrate derived from pyroclastic volcanic material is characterized by high porosity and surface area. Volcanic tuff is a reliable substrate for soilless systems. It has a good acidity resistance, cation exchange capacity, and aeration (Nawasreh et al., 2015; Polat et al., 2004). The total porosity of volcanic tuff ranges from $60 \%$ to $80 \%$ depending on its origin and the sieving/grinding process (Raviv and Lieth, 2008). Croton (Codiaeum variegatum) that was grown in perlite and amended with volcanic tuff was able to use $29 \%$ less water and fertilizer than when grown in peatmoss-perlite medium (Karam et al., 2004). Growing cherry tomato (Solanum lycopersicum) in volcanic tuff resulted in higher marketable yield than perlite and sand substrate (AlAjmi et al., 2009). However, commercial tuff particle size available for soilless agriculture ranges from $\leq 1$ to $10 \mathrm{~mm}$. Given that particle diameter can significantly affect substrate water availability and aeration, it is a crucial prerequisite to determine the appropriate particle size for successful plant growth in soilless system using volcanic tuff. Overall, for efficient use of volcanic tuff as a soilless substrate for lily production, it is essential to identify an optimal particle-size range that potentially improves growth and flower quality. The objective of this study was to assess the influence of tuff substrate size on growth and flower quality of two asiatic hybrid lily cultivars using soilless system in greenhouse conditions.

\section{Material and methods}

Plant material, greenhouse SET UP, AND SUBSTRATE GRADE TREATMENTS. The study was carried out at the University of Jordan, Amman (lat. $32^{\circ} 0^{\prime} 40.4316^{\prime \prime} \mathrm{N}$, long. $35^{\circ} 52^{\prime} 20.3628^{\prime \prime} \mathrm{E}$ ) between Aug. and Dec. 2015. During the study, maximum temperature was $26 \pm$ $4{ }^{\circ} \mathrm{C}$ and minimum temperature was $16 \pm 2{ }^{\circ} \mathrm{C}$. Two bulbs of asiatic hybrid lily cultivars Ercolano and Fangio were planted at $15-\mathrm{cm}$ depth in a 12 - $\mathrm{L}$ pot $(30-\mathrm{cm}$ diameter $)$. Pots were filled with 10 -L-black volcanic tuff. Tuff parent material was from Um Al-Qottain area (lat. $32^{\circ} 17^{\prime} 5.3088^{\prime \prime} \mathrm{N}$, long. 36 $36^{\prime} 5.58^{\prime \prime} \mathrm{E}$ ). A layer (about $4 \mathrm{~cm}$ ) of coarse tuff ( 4 to $8 \mathrm{~mm}$ ) was placed in the bottom of each pot to facilitate container drainage. In addition, a geotextile filter membrane separated the two tuff layers (i.e., experimental and drainage layers). Five tuff grades were used. These sizes were 0 to 2,0 to 4,0 to 8,2 to 4 , and 4 to $8 \mathrm{~mm}$. Tuff particles 0 to 2,0 to 4 , and 0 to $8 \mathrm{~mm}$ were screened to pass through a series of three screen sizes $(2,4$, and $8 \mathrm{~mm}$, respectively). For 2 to 4 and 4 to $8 \mathrm{~mm}$, two screens were used ( 2 and $4 \mathrm{~mm}$ and 4 and $8 \mathrm{~mm}$, respectively). Five tuff samples were collected from each treatment. Then, substrate WHC and bulk density were determined using the procedure of Brady and Weil (1996) (Table 1). Fertigation was applied daily (about $600 \mathrm{~mL}$ ) using two drip emitters $\left(2 \mathrm{~L} \cdot \mathrm{h}^{-1}\right)$. The same volume of fertigation was applied to all tuff treatments regardless of $\mathrm{WHC}$. Because an open soilless system was used, leachate was observed in all treatments. However, no signs of dryness or saturation were observed in containers throughout the study period. Fertigation solution $\mathrm{pH}$ and EC were 6.2 and $2.4 \mathrm{dS} \cdot \mathrm{m}^{-1}$, respectively. Fertigation was scheduled using irrigation controller (X-Core ${ }^{\circledR}$; Hunter Industries, San Marcos, CA). The final composition of the fertigation solution was $205 \mathrm{mg} \cdot \mathrm{L}^{-1}$ nitrate, $172 \mathrm{mg} \cdot \mathrm{L}^{-1}$ potassium, $36 \mathrm{mg} \cdot \mathrm{L}^{-1}$ phosphorus, $95 \mathrm{mg} \cdot \mathrm{L}^{-1}$ calcium, $34 \mathrm{mg} \cdot \mathrm{L}^{-1}$ magnesium, $40 \mathrm{mg} \cdot \mathrm{L}^{-1}$ iron (Fe-ethylenediaminetetraacetic acid), $65 \mathrm{mg} \cdot \mathrm{L}^{-1}$ manganese, $15 \mathrm{mg} \cdot \mathrm{L}^{-1}$ boron, $40 \mathrm{mg} \cdot \mathrm{L}^{-1}$ zinc, and $5 \mathrm{mg} \cdot \mathrm{L}^{-1}$ copper.

Plant morphophysiological AND SUBSTRATE MEASUREMENTS.
Chlorophyll fluorescence $\left(\mathrm{F}_{\mathrm{v}} / \mathrm{F}_{\mathrm{m}}\right)$ and chlorophyll content index (SPAD) were determined twice per month on five fully mature leaves (per experimental unit). Chlorophyll fluorescence was measured using a chlorophyll fluorometer (OS1-FL; Opti-Sciences, Hudson, NH) and SPAD using a chlorophyll meter (CCM-200 plus; Opti-Sciences). Measurements were taken between 1100 and $1300 \mathrm{HR}$ from fully expanded and sun-exposed leaves. Substrate leachate was collected from each pot once per week, then $\mathrm{pH}$ and $\mathrm{EC}$ were measured using $\mathrm{pH}$ meter (pp-203 $\mathrm{pH} / \mathrm{mV} /$ Temp meter; GOnDO Electronic Co., Taipei, Taiwan) and EC meter (YK-22CT; Lutron Electronic Enterprise Co., Taipei, Taiwan).

Number of days to flowering, flower length, and number of flowers per stem were determined during flowering stage. Flowering day was the number of days from the time of planting to first bud bloom on each stem. At the end of the experiment, shoot length, leaf fresh weight, leaf area, and root dry weight were determined. Total leaf area per plant was measured using a leaf area meter (AM350; ADC BioScientific, Hoddesdon, UK). Shoot and roots were oven-dried for $24 \mathrm{~h}$ at $70^{\circ} \mathrm{C}$ to determine dry weight. Roots were washed free of substrate before oven-drying.

Statistical analysis. Analyses were conducted using SAS software (version 9.4 for Windows; SAS Institute, Cary, NC). A randomized complete block design with five treatments (different tuff grades) replicated five times was used. Shoot and root morphology, physiology, substrate properties, and flower quality were statistically analyzed by the analysis of variance and means separated

Table 1. Water holding capacity and bulk density of five tuff (granulated volcanic material) treatments differing in particle-size substrate.

\begin{tabular}{lcc}
\hline Tuff grade $(\mathbf{m m})^{\mathrm{z}}$ & Water holding capacity $(\%)^{\mathrm{y}}$ & Bulk density $\left(\mathrm{g} \cdot \mathrm{cm}^{-\mathbf{3}}\right)^{\mathbf{x}}$ \\
\hline 0 to 2 & $35.88 \mathrm{a}^{\mathrm{w}}$ & $1.43 \mathrm{a}$ \\
0 to 4 & $31.39 \mathrm{ab}$ & $1.12 \mathrm{~b}$ \\
0 to 8 & $28.12 \mathrm{~b}$ & $1.11 \mathrm{~b}$ \\
2 to 4 & $22.36 \mathrm{c}$ & $0.99 \mathrm{c}$ \\
4 to 8 & $11.74 \mathrm{~d}$ & $0.94 \mathrm{c}$ \\
\hline
\end{tabular}

${ }^{\mathrm{z}} 1 \mathrm{~mm}=0.0394$ inch

${ }^{y}$ Water holding capacity is the total amount of water tuff substrate can hold $\mathrm{l}$ h after fertigation.

${ }^{\mathrm{x}}$ Bulk density is the weight of oven-dried tuff divided by the volume of tuff substrate; $\mathrm{l} \mathrm{g} \cdot \mathrm{cm}^{-3}=0.5780 \mathrm{oz} / \mathrm{inch}^{3}$.

wNumbers followed by the same letter within a column are not significantly different according to Fisher's least significant difference test $(P \leq 0.05)$. 
by Fisher's least significant difference test.

\section{Results and discussion}

SUBSTRATE PHYSICAL AND CHEMICAL PROPERTIES. Coarse particles substrate had lower WHC and bulk density compared with finer substrate (Table 1). For example, WHC for 0 to $2 \mathrm{~mm}$ (fine texture) substrate was $36 \%$ and bulk density was $1.43 \mathrm{~g} \cdot \mathrm{cm}^{-3}$. In contrast, WHC for 4 to $8 \mathrm{~mm}$ (coarse texture) was $12 \%$ and bulk density was $0.94 \mathrm{~g} \cdot \mathrm{cm}^{-3}$. WHC and bulk density decreased in parallel with increasing particle size, which is consistent with the results of Wallach et al. (1992). Fine soil particles normally have higher total surface area and hold more water and nutrients compared with coarse particles (Brady and Weil, 1996). Conversely, coarse particles have higher air-filled porosity that might improve root aeration (Drzal et al., 1999; Gizas and Savvas, 2007). Allaire et al. (1996) found that low air-filled porosity caused oxygen deficiency in peat substrate. Moreover, fine-grade substrate has higher concentration of salts, especially at the top layer of the growing medium. In our study, EC increased over time and $\mathrm{pH}$ decreased over time in all treatments. The high cation exchange capacity of tuff is likely the cause of the increase in EC over time as cations are retained in the substrate. The 0 to 2 -mm tuff treatment had higher EC and $\mathrm{pH}$ than 0 to $4-, 0$ to $8-, 2$ to $4^{-}$, and 4 to $8-\mathrm{mm}$ tuff treatments across the experimental period (Fig. 1). For 0 to $2-\mathrm{mm}$ tuff treatment, substrate EC ranged from 3 to $3.5 \mathrm{dS} \cdot \mathrm{m}^{-1}$ measured 30-80 d after planting. Substrate $\mathrm{pH}$ for the same treatment ( 0 to $2 \mathrm{~mm}$ ) was between 7.5 and 8.2. However, for the 0 to 8 and 4 to 8 tuff treatments, EC and $\mathrm{pH}$ ranged from 2.5 to $3.0 \mathrm{dS} \cdot \mathrm{m}^{-1}$ and 7 to 7.5 , respectively. Although optimal $\mathrm{pH}$ for most crops (including lily) ranges from 6.0 to 6.5 , higher $\mathrm{pH}$ levels (6.5 to 7.0$)$ may not cause serious injuries (Adams, 2002; Dole and Wilkins 2005). In fact, no signs of phytotoxicity were observed for any of the treatments over the experimental period.

Plant growth and Flower QUALITY. Leaf visual quality such as leaf size and greenness is a key factor

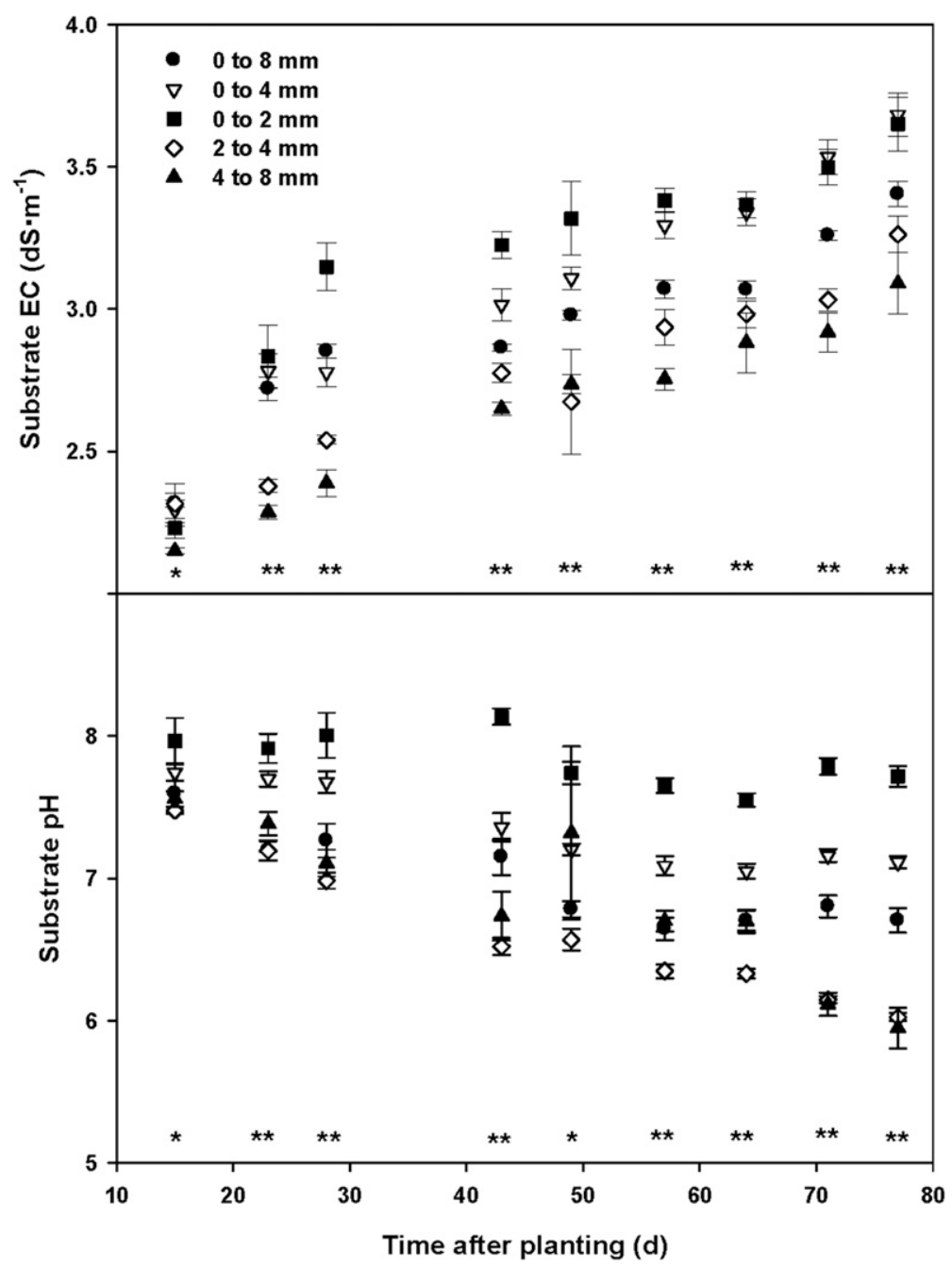

Fig. 1. Electrical conductivity (EC) and $\mathrm{pH}$ of five tuff (granulated volcanic material) substrate grades differing in particle size. Measurements were sampled from lily containers twice per month between Aug. and Dec. 2015. Closed and open symbols represent mean $\pm \mathrm{SE}$ for different tuff grades; * and ** represent significant difference between tuff substrates at 0.05 and 0.01 , respectively; $1 \mathrm{dS} \cdot \mathrm{m}^{-1}=1 \mathrm{mmho} / \mathrm{cm}, 1 \mathrm{~mm}=0.0394$ inch.

Table 2. Leaf fresh weight, leaf area, and shoot and root dry weight for 'Ercolano' and 'Fangio' asiatic hybrid lily grown in different tuff (granulated volcanic material) grades in greenhouse conditions between Aug. and Dec. 2015.

\begin{tabular}{|c|c|c|c|c|c|c|c|c|}
\hline \multirow{2}{*}{$\begin{array}{l}\text { Tuff } \\
\text { grade }(\mathrm{mm})^{\mathrm{z}}\end{array}$} & \multicolumn{2}{|c|}{ Leaf fresh wt $(g)^{z}$} & \multicolumn{2}{|c|}{ Leaf area $\left(\mathrm{cm}^{2}\right)^{\mathrm{z}}$} & \multicolumn{2}{|c|}{ Shoot dry wt (g) } & \multicolumn{2}{|c|}{ Root dry wt (g) } \\
\hline & Ercolano & Fangio & Ercolano & Fangio & Ercolano & Fangio & Ercolano & Fangio \\
\hline 0 to 2 & $29 \mathrm{a}^{\mathrm{y}}$ & $27 \mathrm{c}$ & $895 \mathrm{a}$ & $826 \mathrm{c}$ & $5.14 \mathrm{a}$ & $5.2 \mathrm{~b}$ & $0.78 \mathrm{a}$ & $0.94 \mathrm{ab}$ \\
\hline 0 to 8 & $32 \mathrm{a}$ & $32 \mathrm{bc}$ & 992 a & 977 bc & $5.23 \mathrm{a}$ & $7.2 \mathrm{ab}$ & $1.08 \mathrm{a}$ & $0.90 \mathrm{ab}$ \\
\hline 2 to 4 & $27 \mathrm{a}$ & $35 \mathrm{~b}$ & $844 a$ & $1,091 \mathrm{~b}$ & $5.95 \mathrm{a}$ & $8.3 \mathrm{ab}$ & $0.91 \mathrm{a}$ & $0.72 \mathrm{~b}$ \\
\hline 4 to 8 & $28 \mathrm{a}$ & $35 \mathrm{~b}$ & $863 \mathrm{a}$ & $1,089 \mathrm{~b}$ & $5.37 \mathrm{a}$ & $9.2 \mathrm{a}$ & $0.72 \mathrm{a}$ & $0.58 \mathrm{~b}$ \\
\hline
\end{tabular}

${ }^{\mathrm{z}} 1 \mathrm{~mm}=0.0394$ inch, $1 \mathrm{~g}=0.0353 \mathrm{oz}, 1 \mathrm{~cm}^{2}=0.1550$ inch $^{2}$.

${ }^{y}$ Numbers followed by the same letter within a column are not significantly different according to Fisher's least significant difference test $(P \leq 0.05)$. 
in marketing lily flowers (McKenzie, 1989). In our experiment, tuff particle size significantly affected leaf fresh weight, leaf area, shoot dry weight, and root dry weight of 'Fangio' asiatic hybrid lily (Table 2). However, root and shoot growth of the 'Ercolano' asiatic hybrid lily grown under different particle size was statistically similar across all tuff treatments. In addition, no significant difference in chlorophyll content (SPAD) and fluorescence was noticed between treatments across cultivars and over the experimental period (Fig. 2). Gizas and Savvas (2007) found that rose (Rosa Xhybrida 'First Red') proved to be more tolerant to differences in the air-to-water balance than gypsophila (Gypsophila paniculata 'Perfecta') in the root zone resulting from variations in the physical properties of the substrate. In this study, tuff grade 0 to $2 \mathrm{~mm}$ had the lowest shoot fresh weight and leaf area in 'Fangio'. Root dry weight was lower in all tuff treatments except 0 to $4 \mathrm{~mm}$ in 'Fangio' (Table 2). Fine particles reduced aeration, which was a crucial prerequisite to manage plant growth successfully with soilless systems (Deepagoda et al., 2013). Interestingly, 'Fangio' grown in 0 to $4-\mathrm{mm}$ substrate had better leaf area and shoot fresh weight than other tuff treatments.

In the cut flowers industry, flower size, number of flowers per stem, and stem length are the key elements of high-quality flowers (Burchi et al., 2010; Woodson, 1991). In our study, 0 to $2-\mathrm{mm}$ substrate reduced all flower quality parameters (Table 3). Flower quality parameters were significantly higher in 0 to $4^{-}, 2$ to $4^{-}$, and 4 to 8 - $\mathrm{mm}$ tuff. Interestingly, 0 to $4-\mathrm{mm}$ substrate had an optimal and a consistent flower quality (plant height, number of flowers per plant, and flower length) across both cultivars (Table 3 ). Gizas and Savvas (2007) found that growing gypsophila flowers in 0 to $5-\mathrm{mm}$ pumice substrate had higher flower yield compared with a coarse grade, 0 to $8 \mathrm{~mm}$.

\section{Conclusions}

Appropriate WHC and good aeration are important features for an efficient substrate. In our study, 0 to $2-\mathrm{mm}$ substrate had higher WHC, EC, and bulk density compared with 2 to 4,0 to 4,0 to 8 , and 4 to $8 \mathrm{~mm}$. As a result, 0 to $2-\mathrm{mm}$ tuff had lower shoot and flower quality than other tuff treatments. Interestingly, both 'Fangio' and 'Ercolano' grown in 0 to 4 - $\mathrm{mm}$ substrate had an optimal and consistent shoot and flower quality characteristics when compared with 0 to $2-, 0$ to 8 -, and 4 to $8-\mathrm{mm}$ substrates. Volcanic tuff is proving to be a reliable substrate for soilless systems compared with other soilless substrates such as perlite and sand. Volcanic tuff has high cation exchange capacity and aeration, and it can last for many years due to its stability and resistant to solubility or degradation (Nawasreh et al., 2015; Polat et al., 2004; Silber and Raviv, 1996). Accordingly, using 0 to $4-\mathrm{mm}$ substrate holds promise for improving growth and flower quality of

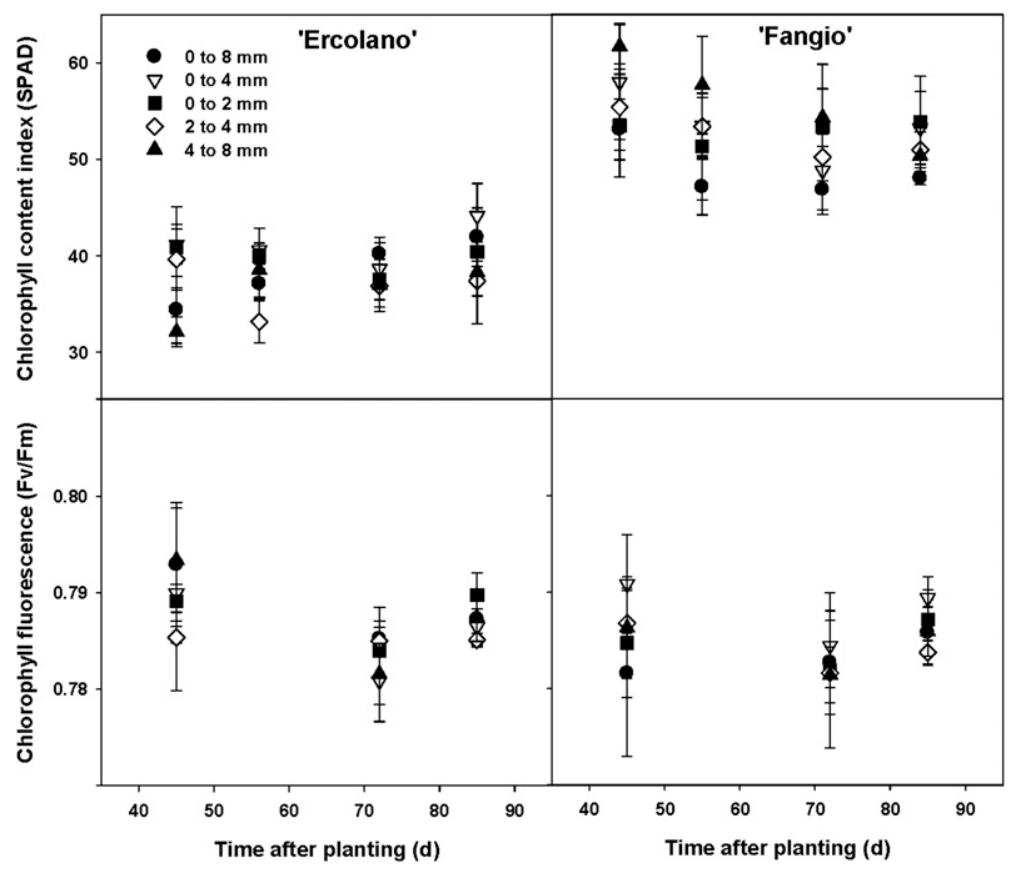

Fig. 2. Chlorophyll content index (SPAD) and chlorophyll florescence of 'Ercolano' and 'Fangio' asiatic hybrid lily grown in different tuff (granulated volcanic material) grades. Measurements were determined twice per month on five fully mature leaves between Aug. and Dec. 2015; $1 \mathrm{~mm}=0.0394$ inch.

Table 3. Plant height, flower number, flower length, and number of days to flowering for 'Ercolano' and 'Fangio' asiatic hybrid lily grown in different tuff (granulated volcanic material) grades in greenhouse conditions between Aug. and Dec. 2015.

\begin{tabular}{|c|c|c|c|c|c|c|c|c|}
\hline \multirow[b]{2}{*}{ Tuff grade $(\mathrm{mm})^{\mathrm{z}}$} & \multicolumn{2}{|c|}{ Plant ht $(\mathrm{cm})^{\mathrm{z}}$} & \multicolumn{2}{|c|}{ Flower (no./plant) } & \multicolumn{2}{|c|}{ Flower length $(\mathrm{cm})$} & \multicolumn{2}{|c|}{ Time to flowering (d) } \\
\hline & Ercolano & Fangio & Ercolano & Fangio & Ercolano & Fangio & Ercolano & Fangio \\
\hline 0 to 2 & $62.4 \mathrm{a}^{\mathrm{y}}$ & $71.0 \mathrm{~b}$ & $3.3 \mathrm{bc}$ & $3.5 \mathrm{~b}$ & $12.5 \mathrm{bc}$ & $13.0 \mathrm{c}$ & $80.4 \mathrm{a}$ & $70.0 \mathrm{a}$ \\
\hline 0 to 8 & $58.1 \mathrm{a}$ & $82.0 \mathrm{a}$ & $2.4 \mathrm{c}$ & $3.8 \mathrm{~b}$ & $11.2 \mathrm{c}$ & $16.5 \mathrm{~b}$ & $83.0 \mathrm{a}$ & $70.3 \mathrm{a}$ \\
\hline 2 to 4 & $60.4 \mathrm{a}$ & $85.1 \mathrm{a}$ & $4.2 \mathrm{ab}$ & $4.8 \mathrm{a}$ & $15.0 \mathrm{ab}$ & $17.1 \mathrm{~b}$ & $75.6 \mathrm{a}$ & $68.0 \mathrm{a}$ \\
\hline 4 to 8 & $59.6 \mathrm{a}$ & $84.5 \mathrm{a}$ & $4.2 \mathrm{ab}$ & $5.4 \mathrm{a}$ & $17.1 \mathrm{a}$ & $17.0 \mathrm{~b}$ & $76.6 \mathrm{a}$ & $67.2 \mathrm{a}$ \\
\hline
\end{tabular}

${ }^{\mathrm{z}} \mathrm{l} \mathrm{mm}=0.0394$ inch, $1 \mathrm{~cm}=0.3937$ inch.

${ }^{y}$ Numbers followed by the same letter within a column are not significantly different according to Fisher's least significant difference test $(P \leq 0.05)$. 
asiatic hybrid lily grown under soilless culture.

\section{Literature cited}

Adams, P. 2002. Nutritional control in hydroponics, p. 211-261. In: D. Savvas and H. Passam (eds.). Hydroponic production of vegetables and ornamentals. Embryo Publ., Athens, Greece.

Al-Ajmi, A., G. Al-Karaki, and Y. Othman. 2009. Effect of different substrates on fruit yield and quality of cherry tomato grown under recalculating soilless system. Acta Hort. 807:491-494.

Allaire, S., J. Caron, I. Duchesne, L. Parent, and J. Rioux. 1996. Air-filled porosity, gas relative diffusivity, and tortuosity: Indices of Prunus $\times$ cistena sp. growth in peat substrates. J. Amer. Soc. Hort. Sci. 121:236-242.

Bohne, H. and A. Wrede. 2005. Investigations of physical properties of substrates. Eur. J. Hort. Sci. 70(1):1-6.

Brady, N. and R. Weil. 1996. The nature and properties of soils. 12th ed. Prentice Hall, Upper Saddle River, NJ.

Burchi, G., D. Prisa, A. Ballarin, and P. Menesatti. 2010. Improvement of flower color by means of leaf treatments in lily. Sci. Hort. 125:456-460.

Cannavo, P. and J. Michel. 2013. Peat particle size effects on spatial root distribution, and changes on hydraulic and aeration properties. Sci. Hort. 151:1121 .

Caron, J., L. Riviere, and G. Guillemain. 2005. Gas diffusion and air-filled porosity: Effect of some oversize fragments in growing media. Can. J. Soil Sci. 85:5765.

Deepagoda, T., J. Lopez, P. Møldrup, L. De Jonge, and M. Tuller. 2013. Integral parameters for characterizing water, energy, and aeration properties of soilless plant growth media. J. Hydrol. (Amst.) 502:120-127.
Dole, J. and H. Wilkins. 2005. Floriculture principles and species. 4 th ed. Pearson Prentice Hall, Upper Saddle River, NJ.

Drzal, M., W. Fonteno, and D. Cassel 1999. Pore fraction analysis: A new tool in substrate analysis. Acta Hort. 481:43-54.

García, I., R. Mendoza, and M. Pomar. 2008. Deficit and excess of soil water impact on plant growth of Lotus tenuis by affecting nutrient uptake and arbuscular mycorrhizal symbiosis. Plant Soil 304:117-131

Gizas, G. and D. Savvas. 2007. Particle size and hydraulic properties of pumice affect growth and yield of greenhouse crops in soilless culture. HortScience 42:12741280 .

Hu, Y. and U. Schmidhalter. 2005. Drought and salinity: A comparison of their effects on mineral nutrition of plants. J. Plant Nutr. Soil Sci. 168:541-549.

Huang, L., B.-C. Dong, W. Xue, Y.-K. Peng, M.-X. Zhang, and F.-H. Yu. 2013. Soil particle heterogeneity affects the growth of a rhizomatous wetland plant. PLoS One 8:1-6.

Ingram, D., R. Henley, and T. Yeager. 1993. Growth media for container grown ornamental plants. Univ. Florida. Coop. Ext. Serv. Bul. 241

Karam, K., M. Mohammad, and N. AlLataifeh. 2004. Growth and irrigation requirements of croton in substrates amended with pre-charged zeolitic tuff. J. Plant Nutr. 27:1779-1794.

McKenzie, K. 1989. Potted lily made easy: The new, naturally short Asiatic lily varieties. GrowerTalks 52(4):48-58.

Munoz, C., R. Soto, and J. Valenzuela. 1993. Effect of chemical and physical potting media characteristics on growth of container-grown rabbit eye blueberries. Acta Hort. 346:162-172.

Murphy, V., K. Moore, M. Griffith, and C. Husby. 2013. Improving conservation through cultivation: Nine container substrates influence growth of a rare cycad, Zamia pumila L. HortScience 48:11681172.

Nawasreh, M., S. Yasin, and N. Zurquiah. 2015. Zeolitic tuff, Natural Resources Authority (Mineral Status and Future Opportunity). Amman, Jordan. 8 Feb. 2017. <http://www.memr.gov.jo/ EchoBusV3.0/SystemAssets /PDFs/ AR/MineralTR/Zeolitic\%20Tuff.pdf>.

Polat, E., M. Karaca, H. Demir, and A. Naci-Onus. 2004. Use of natural zeolite (clinoptilolite) in agriculture. J. Fruit Ornamental Plant Res. 12:183-189.

Raviv, M. and J. Lieth. 2008. Soilless culture: Theory and practice. 1st ed. Elsevier Science, Amsterdam, The Netherlands.

Richards, D., M. Lane, and D. Beardsell. 1986. The influence of particle-size distribution in pine bark, sand, and brown coal potting mixes on water supply, aeration and plant growth. Sci. Hort. 29:114.

Samadi, A. 2011. Effect of particle size distribution of perlite and its mixture with organic substrates on cucumber in hydroponics system. J. Agr. Sci. Technol. 13:121-129.

Silber, A. and M. Raviv. 1996. Effects on chemical surface properties of tuff by growing rose plants. Plant Soil 186:353360

Sloan, J., M. Hegemann, and S. George. 2008. Dual-function growth medium and structural soil for use as porous pavement. J. Environ. Qual. 37:2248-2255.

Wallach, R., F. Da Silva, and Y. Chen. 1992. Hydraulic characteristics of tuff (scoria) used as a container medium. J. Amer. Soc. Hort. Sci. 117:415-421.

Woodson, W. 1991. Gene expression and flower senescence, p. 317-381. In: F. Singh (ed.). Genetics and breeding of ornamentals species. Kluwer Academic Publ., Norwell, MA. 